\title{
Does the type of degree predict different levels of satisfaction and loyalty? A brand equity perspective
}

Marta Retamosa, Angel Millán and Miguel Moital

This is an author's version of manuscript accepted for publication in Corporate Reputation Review on 28th June 2019. Please refer to:

Retamosa, M., Millan, A. and Moital, M. (2019). Does the Type of Degree Predict Different Levels of Satisfaction and Loyalty? A Brand Equity Perspective, Corporate Reputation Review, DOI: 10.1057/s41299-019-00073-1

\section{Dr. Marta Retamosa (Corresponding Author) marta.retamosa@uclm.es} Angel.millan@uclm.es
Dr. Angel Millán-Campos

Lecturer in Marketing

Universidad de Castilla-La Mancha, Comercialización e Investigación de Mercados Facultad de derecho y ciencias sociales. Ronda de Toledo Ciudad Real, Ciudad Real, ES 13003

Principal Academic in Marketing Universidad de Castilla-La Mancha, Comercialización e Investigación de Mercados

Facultad de derecho y ciencias sociales. Ronda de Toledo Ciudad Real, Ciudad Real, ES 13003

Dr. Miguel Moital mmoital@bournemouth.ac.uk
Principal Academic in Events Management

Bournemouth University Dorset House, Talbot Campus Fern Barrow BH12 5BB Poole, UK

Bournemouth, UK 


\title{
Does the type of degree predict different levels of satisfaction and loyalty? A brand equity perspective
}

\begin{abstract}
There is a growing need to evaluate the factors that enable universities to attract and retain students. University brand managers require a better understanding of how students evaluate and interact with their brand. These processes can differ significantly across disciplines and degrees because of their different educational goals, teaching practice, course content, assessment and physical resources required. This study examines disciplinary differences in brand equity dimensions (service quality, loyalty, community, brand personality, shared values and brand trust) across three degrees: business, nursing and engineering. Data from 1.039 university students of a multi-campus Spanish public university was analysed using ANOVA and logistic regression analysis. Findings showed that students state different level of satisfaction and loyalty depending on the degree course they are taking. This study highlights relevant issues for brand management in Higher Education Institutions.
\end{abstract}

KEYWORDS: brand equity; disciplinary differences; higher education; university branding; loyalty.

\section{INTRODUCTION}

Universities have been led to compete for student enrolments in response to trends of global student mobility and diminishing university funding. The intensifying market pressures faced by higher education institutions have forced many to adopt marketing and corporate image strategies (Asaad et al, 2014; Palmer et al, 2016). Because of these trends, the main objective seems to be to work on brand building underpinned on a two-way communication within the brand architecture, recognising the contributions of schools and faculties to brand identity (Hemsley-Brown and Goonawardana, 2007). A strong university brand has the ability to capture customer preference and loyalty (Pinar et al, 2014) and therefore the amount of resources invested in branding universities has undergone a strong upward trend (Rolfe, 2003). However, the literature on branding in higher education (HE) is limited, despite the assertion that 'HE and branding go back a long way' as claimed by Temple (2006). The view that branding in the non-profit sector creates unhealthy competition being a wasteful of resources is refuted by the recognition that strong brands are strategic assets creating brand value in the sector (Quelch and Laidler-Kylander, 2006; Keller, 2007). Despite universities 
being a mixture of campuses, courses, programs and degrees, branding has become crucial to manage this particular service (Chapleo, 2007).

Numerous studies have demonstrated that students are one of the most important stakeholders in HE sector because they are the main source of revenues for the institution (Eagle and Brennan, 2007; Marzo et al, 2007; Safon, 2009; $\mathrm{Ng}$ and Forbes, 2009). Universities are competing to recruit more students, particularly due to marketization and globalization (Faham et al, 2017; Yu et al, 2018). The way universities manage their relationship with students and how students perceive their institution's brand can have a great impact on student satisfaction with the institution (Watkins and Gonzenbach, 2013; Dholakia and Acciardo, 2014). More recently, Foroudi et al (2019) demonstrated the pivotal role of value co-creation behaviour in creating and sustaining university brand image and reputation. Alessandri et al (2006) commented on the lack of research focused on the influence of university branding on students' commitment, satisfaction, trust, and brand equity. Yet, understanding and knowing the expectations of students may be a source of information for the institution due to being a valuable input to the creation of service quality strategy (Sander et al, 2000), leading to gaining an advantage on the HE market.

Wæraas and Solbakk (2009) stated that universities are too complex and fragmented to both understand and express as single identity organization. When the presence of multiple brands or sub-brands within a university is taken into consideration, the perception of the university brand can be significantly different according to different faculties, degrees areas or specific degrees. This contention is supported by the fact that it is generally accepted that academic disciplines vary in their views of application of practical problems, cognitive processes, and concern with life systems, beliefs about collaboration, faculty time commitments and scholarly output (Becher, 1987; Umbach and Porter, 2002). The relevance of a discipline-based approach to HE is further highlighted by authors such as Heiland and Rosenthal (2011) and Kuh et al (2015), since they establish that disciplinary considerations must be critical to assessment in order to avoid imposing generic assessment practices that are not well adapted to subject matter itself. Swarat et al (2017) concurred by demonstrating that adaptation to unique disciplinary differences is a key factor for developing and implementing meaningful student learning outcomes.

Although the presence of multiple brands (i.e., sub-brands) is expected, there may be shared meanings and identity elements across the various brands (Pinar et al, 2014). Research on learning, teaching and assessment has recognised the relevance of an institution-wide approach that reflects common principles and practices. Yet, an institutional assessment 
framework can be successful if it allows faculty to express their unique disciplinary tradition and to adapt the framework to the specific context of their subject field (Swarat et al, 2017). University rankings appear to reflect this dual institutional and disciplined specific perspectives, by evaluating the entire institution as well performance in key disciplinary areas (Lynch, 2015).

While a great deal of work about differences between disciplines has been carried out, little research has been done to examine the influence of different disciplines on student outcomes and evaluations (Umbach and Porter, 2002; Swarat et al, 2017). Yet, research on disciplinary differences is critical for informing policy as well as supporting targeted action at managerial level. There are important implications for personnel policies, student evaluation of teaching system and academic programmes, staff development policies and marketing strategies. The strong influence of discipline on academics' beliefs, on teaching and on students' learning, suggests that disciplines need to be subjected to a greater systematic study. The potential of such research to contribute to inform policy at both institutional and institutional levels is fundamental to the fair, effective and responsible governance of higher education (Neumann, 2001).

Despite the notable contributions of previous studies, research on branding evaluation of students' satisfaction in the context of disciplinary areas is limited. Some authors simply assessed whether level of student satisfaction varied across faculty (La Rocca et al, 2017) while others (Denson et al, 2010) compared student satisfaction across broad disciplines (natural and physical sciences vs. engineering and related technologies). No specific study has sought to examine how disciplinary differences can determine student evaluation of university brands. In addition, while high education marketing literature has examined the brand equity dimensions in different contexts, specific studies that examine disciplinary differences do not appear to have been developed. Yet, Pinar et al (2011) have suggested research should take into account the perspectives of different degrees within a University. This research attempts to fill this gap by exploring potential differences in brand equity dimensions across degrees with essential disciplinary differences. According to the main objective, this study has been designed to: 1) compare student perceptions of brand equity by discipline/degrees, and 2) examine the extent to which degree type influences student loyalty to the university. 


\section{LITERATURE REVIEW}

\subsection{Disciplinary differences}

A comprehensive understanding of learning and teaching processes involves an in-depth knowledge of the context and the culture in which teaching occurs and the attitudes of both academics and students about teaching, educational goals, values, philosophies and orientations (Neumann, 2001). One common way of addressing context and culture focuses on examining how student evaluations vary across degree, faculty or disciplinary area. Disciplinary related differences have been analysed in various areas of academic practice, including academics' relationship to knowledge, the relationship between learners and educators, and the type of knowledge that learners are expected to obtain about their subject (Kemp and Jones, 2007).

The classification of the disciplines has most commonly been interpreted using Biglan's (1973a,1973b) classification of disciplines (i.e. Neumann et al, 2002; Coughlan and Perryman, 2011). Biglan (1973a,1973b) suggested a categorisation scheme for disciplines using three classification criteria (Kember and Leung, 2011): degree of consensus paradigm development (hard versus soft); presence of practical application (pure versus applied); presence of living organism (life versus non-life). According to these criteria academic disciplines can be clustered into four main groups with different epistemological characteristics: hard pure, hard soft, hard applied, soft applied (Neumann et al, 2002; Coughlan and Perryman, 2011), with each of these further divided into life and non-life.

Previous studies have highlighted a number of significant differences between hard and soft disciplines, notably in relation to educational goals, teaching practice, course content, assessment and physical resources required. With regards to educational goals, hard fields assign greater importance to student career development and emphasise cognitive goals such as learning facts, principles and concepts (Braxton, 1995; Barnes et al, 2001). Disciplinary knowledge is considered more relevant than generic skills (Chang and Fong, 2018). In contrast, soft fields emphasize "student development" more as their primary teaching objective (Barnes et al, 2001), placing greater relevance on broad general knowledge, on student character development and on effective thinking skills such as critical thinking (Braxton, 1995). Teaching practice in hard disciplines is more focused on student research experience, while soft fields it is concentrated more on student growth, and development, discussion, oral and communication skills (Neumann, 2001).

In terms of course content, independently of the method of providing knowledge (print, faceto-face, or online) content in pure and hard disciplines is typically fixed, accumulative, and quantitatively measured, with teaching and learning activities focused and instructive. In 
contrast, content in soft disciplines tends to be freer and more qualitative, and teaching and learning activities are highly constructive and interpretive (Newman et al, 2002). Research has also shown differences in assessment focus, with hard pure applied disciplines emphasizing practical competence, application of theory to practice and factual understanding, while soft applied disciplines based on personal growth, intellectual breadth and application of theory to practice (Jessop and Maleckar, 2016). Finally, hard sciences courses, such as engineering, also require specialist physical resources in the form of laboratories and equipment, while soft science courses mostly use the traditional classroom (Coughlan and Perryman, 2011).

Following from the previous discussion, two hypotheses are formulated:

$\mathrm{H} 1$ : The type of discipline/degree influences the evaluation of brand equity dimensions.

$\mathrm{H} 2$ : The type of discipline/degree influences the factors that determine the extent of loyalty to the university.

\subsection{Brand Equity in higher education}

Brand equity is defined as a multi-dimensional variable (Aaker, 1991; Pinar et al, 2011) that refers to the value created in the consumer's mind based on the brand's higher levels of quality, social esteem, trust and self-identification with the brand (Aaker, 1991; Keller, 1993; Schiffman and Kanuk, 2007). It consists of elements such as brand awareness, brand associations, brand personality, perceived quality, brand loyalty (Aaker, 1997) and brand trust (Eakuru and Mat, 2008; Liao and Wu, 2009). Before explaining which dimensions shape this concept within this research, it is necessary to provide some background about brand equity definitions in Higher Education Institutions (HEls) (see Table 1).

In the current context of HEls, several authors showed that trust, satisfaction and commitment play a role in building brand equity. They identified that trust enables more efficient relationships, which could positively affect satisfaction (Anderson and Narus, 1990; Andaleeb, 1996) and commitment (Morgan and Hunt, 1994; Garbarino and Johnson, 1999). Keller (2001) points out that satisfied students tend to feel committed to the institution and consider the university as being trustworthy, which turns into favourable brand equity. In addition, through the provision of quality services, the creation of an emotional link with students or having a unique set of communication and service tools allows universities to gain a good position in the global market (lqbal et al, 2012). Therefore, service quality could be considered as a precursor of satisfaction as other previous studies have concurred to explain (Cronin and Taylor, 1992; Dion et al, 1998; Lee et al, 2000; Douglas et al, 2008). 
Table 1 - Brand equity in higher education

\begin{tabular}{|c|l|}
\hline AUTHOR & \multicolumn{1}{c|}{ CONTRIBUTION } \\
$\begin{array}{c}\text { Hemsley-Brown and } \\
\text { Goonawardana (2007) }\end{array}$ & $\begin{array}{l}\text { The recent economic environment has had a strong negative impact on the } \\
\text { financial situation of most higher education institutions and colleges. As a } \\
\text { result, they have resorted to the brand in their attempt to succeed, and in some } \\
\text { cases to survive in a saturated higher education market }\end{array}$ \\
\hline Chen (2008) & $\begin{array}{l}\text { Provider attributes, product attributes, and marketing activities performed by a } \\
\text { higher education institution will help to generate a better brand equity strategy }\end{array}$ \\
\hline Mazzarol and Soutar (2008) & $\begin{array}{l}\text { Factors such as staff recruitment, location, size, history and international } \\
\text { relations directly influence the quality of higher education }\end{array}$ \\
\hline Whisman (2009) & $\begin{array}{l}\text { Given that the market is becoming more and more complex and competitive, } \\
\text { universities and colleges use brand management strategies to address today's } \\
\text { global challenges }\end{array}$ \\
\hline Mourad, Ennew and & $\begin{array}{l}\text { They proposed a brand equity model adapted to higher education taken into } \\
\text { account five attributes: consumer, supplier, marketing activities, product and } \\
\text { symbolic }\end{array}$ \\
\hline Mourad (2013) & $\begin{array}{l}\text { The brand equity of a higher education institution is an element that influences } \\
\text { the selection process, as it acts as a differentiation tool }\end{array}$ \\
\hline Pinar, Trapp, Girard and Boyt \\
(2014) & $\begin{array}{l}\text { The fundamental factors in creating brand equity in higher education are: (1) } \\
\text { brand awareness, (2) perceived quality, (3) brand associations, (4) } \\
\text { organizational associations, (5) brand loyalty, (6) brand emotions, (7) brand } \\
\text { trust, (8) learning environment, and (9) reputation }\end{array}$ \\
\hline $\begin{array}{c}\text { Dennis, Papagiannidis, } \\
\text { Alamanos and Bourlakis } \\
\text { (2016) }\end{array}$ & $\begin{array}{l}\text { Authors examine the effect of brand attachment and its antecedents on } \\
\text { commitment, satisfaction, trust and brand equity in the context of higher } \\
\text { education institutions }\end{array}$ \\
\hline $\begin{array}{l}\text { Muthors test the multi-dimensionality aspect of the brand equity model, } \\
\text { encompassing brand awareness and brand image in the Higher Education } \\
\text { market and investigating two diverse country samples from the USA (a } \\
\text { developed market), and from Egypt (an emerging market) }\end{array}$ \\
\hline (2019)
\end{tabular}

When HE managers realized and understood that brand equity was a way of gaining differentiation from other universities (Sevier, 2001), they focused on building brand equity through a strong brand name. Two studies (Yavas and Shemwell, 1996; Landrum et al, 1998) highlighted the crucial role that the brand image of a university plays in attitudes towards HE. Ivy (2001) found that establishing images in the mind of the stakeholders is very important and therefore a key influencing factor on a student's willingness to apply to the institution. But research on university brand image, identity, reputation, and meaning seems to be scarce (Arpan et al, 2003; Melewar and Akel, 2005).

In this study, the following dimensions of brand equity are considered: teaching staff, loyalty, community, administrative staff, study programme, facilities and equipment, brand personality, shared values and brand trust. Therefore, below is provided an explanation of the concepts behind those constructs measured in this research. They form the proposed brand equity model, illustrated in Figure 1. 


\section{Figure 1: Brand Equity dimensions considered at the study}

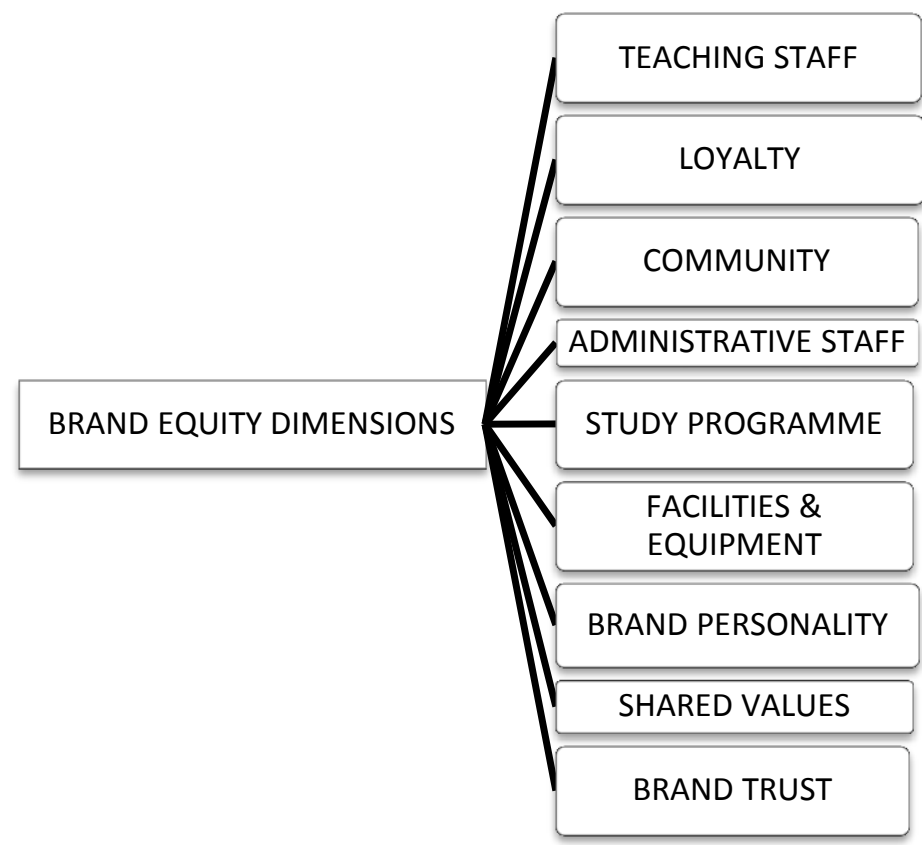

\subsubsection{Perceived quality and reputation}

The relationship between students' expectations and their satisfaction with the quality of the services provided by the institution plays a crucial role in shaping the reputation of academic institutions (Mihanović et al, 2016). The perceived quality and reputation of a HEI can affect the perceptions of an institution's brand characteristics, namely HEl's image, identity, and meaning (Dennis et al, 2016). Perceived quality refers to the judgments of students about a HEl's overall excellence (Zeithaml, 1988), while reputation is the overall value, esteem, and character of a brand that results from people's judgement (Chaudhuri, 2002). In HE, perceived quality and reputation exert strong influence on student choice (Mazzarol and Soutar, 2002; Chen and Hsiao, 2009; Wilkins and Huisman, 2011). Hill (1995) stated that perceived HE service quality could be the product of a number of service encounter evaluations (with administrators, teaching staff, managers and other employees) by students.

Van Vught (2008) also showed that reputation describes the image (comprising quality, influence, trustworthiness) that the institution has. Reputation cannot be managed as well as brand communication because it depends on impressions about the organization's behaviour (Argenti and Druckenmiller, 2004). Becker and Toutkoushian, (2013) established that successful universities attaining prestige have used it to generate demand becoming more prestigious in HE markets. In this research students were asked about the values they shared with institution's and how they perceived the university's trustworthiness. 
Moreover, some authors have demonstrated that a great variety of factors could determine the student's satisfaction (Pinar et al, 2011), including 'facilities'. Price et al (2003) highlight the importance of installations/infrastructures and tangible elements as the main reason for student choice. A great number of studies (LeBlanc and Nguyen, 1997; Joseph et al, 2005) support this determinant of the service quality in HEls. Facilities include all the equipment and tools that support both the academic and the non-academic activities of the institution (Peng and Samah, 2006). Harvey (1995) and Athiyaman (1997) studied the effects of some elements that might influence student satisfaction, and they concluded that library services or computer services were the most valued items when it came to measuring the quality of the HEls. Several studies have demonstrated the positive impact of high quality educational facilities on student achievement and academic staff motivation (Borden, 1995; Delaney, 2001; Thomas and Galambos, 2004). Similarly, Ndirangu and Udoto (2011) found that student life experience through campus facilities might enhance or inhibit the students' core service experience.

Therefore, in order to measure what the students believed about the institution's quality and reputation, the following constructs were built and named as: teaching staff, administrative staff, study programme, facilities and equipment, shared values and brand trust.

\subsubsection{Loyalty}

Many schools have come to realize that is better to invest in order to retain students than to attracting new ones (Elliott and Healy, 2001). That is called loyalty. Customer loyalty is commonly viewed as repeat purchases of a product/service, positive word of mouth along with recommendations to other people to use the product/service (Zeithaml et al, 1996; Oliver, 1999; Lam et al, 2004). In the HE context, previous studies have found that parents enrolling their children at a preferred institution provide positive word of mouth (Malik et al, 2015). Therefore, brand loyalty in the form of support is important in HE, but the consequences differ when compared to common goods because an HE experience has more resulting forms of support behaviours (Stephenson and Yerger, 2014) beyond repeat purchase. In this research, students were asked about facing the possibility of choosing the same university again to keep on studying other courses or to attend postgraduate courses.

\subsubsection{Community}

Brand identification is a key issue for branding strategies in HEls as well (Palmer et al, 2016). Balmer and Liao (2007) defined this concept as 'students'/alumni's defining of the self in terms of an association with the brand of their university alma mater'. Sometimes, the value of the institutions as a brand may enhance the level of students and alumni identification 
when concerned with aspects of social status or certain career opportunities (Asaad et al, 2013). Students with higher self-brand connection levels showed supportive behaviours (advocacy intentions, university affiliation and suggestions for improvement) thereby students tend to communicate their identification with the university to others (Balaji et al, 2016). This research employed a construct measuring a sense of belonging to the university's community as a means to measure the community element of the research model.

Furthermore, a Brand Love statement was included in this construct because previous studies have investigated the application of brand love in a university branding context, highlighting the relevance of the topic (Nguyen and LeBlanc, 2001; Rindfleish, 2003; Hemsley-Brown and Oplatka, 2006). It has been suggested that HE research in the future should consider using brand love as a potential outcome variable (Albert et al, 2013; Batra et al, 2012). Some recent studies are considering this research topic, like Rauschnabel et al (2016) who examined the relationship between university brand personality and brand love in an HE context, advancing as a result the understanding the psychological mechanisms leading to brand love.

\subsubsection{Brand personality}

The brand personality concept in HE is considered as a measure of the link that stakeholders show towards the university (Blackston, 1993) and the main consequence is the creation of brand distinctiveness and differentiation (Watkins and Gonzenbach, 2013). This personality could influence the positive overall image university students have about HEls (Sung and Yang, 2009). Moreover, Bulotaite (2003) found out that when a name of a university is mentioned it evokes associations, emotions and images. A University brand and its associated meanings is an experiential promise that could influence on a student's expectations (Pinar et al, 2011). Many brand personality researchers try to identify these human brand attributes (Aaker, 1997; D'Astous and Boujbel, 2007; Valette-Florence and De Barnier, 2013). Mostly of the scales are based on Aaker's (1997). Thus, one of the main limitations is the application of traditional brand personality measures in HEls (Watkins and Gonzenbach, 2013). Therefore, Universities tend to employ personality attributes in their marketing strategies (Opoku et al, 2008).

\section{METHOD}

\subsection{Measurement}

Measures were adapted from or developed based on extant research. Individual measurement items for the constructs are listed in the Appendix. All scales were Likert-type 
items, with response categories from 1 (strongly disagree) to 10 (strongly agree). Items measuring satisfaction with teaching staff, administrative staff, study programme and facilities, were adapted from previous scales based on Cronin and Taylor (1992). Loyalty items were taken from Nguyen and LeBlanc (2001), Alves (2011) and Grace et al (2012). Community was based on a scale from Mael and Ashforth (1992), Bergkvist and BechLarsen (2010) and Nam et al (2011). Brand personality items were drawn from Beerli et al (2002). The shared values and brand trust items were based on the scales developed by Morgan and Hunt (1994).

\subsection{Sampling}

Students are the main focus of university branding strategies (Ivy, 2008) and the ones who receive the educational services ( $\mathrm{Ng}$ and Forbes, 2009; Pinar et al, 2011). Therefore, we collected data from student at University of Castilla La Mancha, a public, multi-campus university in Spain. UCLM is the sole public university in the region, hosting around 25.00 students. The study was a cluster trial with campuses as clusters and individual students as participants. In order to have a good representation of students from all levels of classification and different colleges across the campuses, we chose convenience sampling to include freshmen, sophomore, junior, and senior level classes from the colleges of business, engineering, and nursing. We did not include post-graduate classes in the sample. We secured a sample of 1.039 undergraduate students from the Business, Nursing and Engineering degrees. This sample size exceeded the requirement of around five observations per scale item which are needed to conduct factor analyses (Hair et al, 1998).

Students from different courses were chosen reflecting disciplines which have their own cognitive and cultural aspects (Becher, 1994). Three discipline areas were selected following Biglan's (1973a,1973b) classification: business administration (soft applied, applied non-life), nursing (soft applied, life) and engineering (hard applied, non-life). These disciplinary groupings were chosen so as to be consistent with the category scheme proposed. The questionnaire was distributed to all business administration, nursing and engineering courses across the four campuses.

\subsection{Data analysis}

Before assessing the relationship between brand equity and degree type, the data was subjected to a factor analysis in order to examine the dimensionality of the scale (Malhotra and Birks, 2007). We employed principle component analysis to find the underlying factors in our brand equity scale. The Kaiser criterion suggested nine factors should be retained, with individual items retained if they loaded on a single factor and the factor loading was above 
0.50 (see Table 2). The coefficient alpha values for each of the nine factors ranged from .871 to .959, exceeding the conventional minimum of 0.7 (Nunnally and Bernstein, 1994), demonstrating high internal consistency and hence reliability of each factor.

In order to examine the relationship between degree type and brand equity, two analyses were undertaken. First, ANOVA was employed to assess whether there were statistically significant differences in brand equity perceptions across different degree (business, nursing and engineering). When differences were found, the Scheffé Test was employed to identify where the differences were. The second analysis focused on assessing the determinants of loyalty using logistic regression. In order to fulfil the requirements of logistic regression, the dependent variable (loyalty) was divided into high loyalty and moderate-low loyalty, with a factor mean value of 6 used as a cut-off point. Logistic regression is useful for predicting an outcome (loyalty, the dependent variable) from a set of predictor variables, in this instance brand equity factors. Four logistic regressions were carried out, one for the entire sample and one for each degree type, with the latter focusing on examining the extent to which the brand equity factors that determine student loyalty level vary across different degree.

\section{RESULTS}

\subsection{Factor analysis. Identifying Brand equity dimensions.}

Cronbach's alpha analysis was used to test each of the factors for internal consistency. All factors showed reliability coefficients above 0.8 , and therefore it can be concluded that the factors are reliable (Bartz, 1999) (see Table 2). The factor contributing the most to variance in the data was Teaching staff (45.0\% of the variance), and comprises thirteen items referring to the tutors' qualifications and competence, willingness to provide help and interest in the student's needs. The second factor contributing the most to overall variance was named loyalty. The nine item factor is a combination of items from behavioural loyalty, satisfaction and perceived value, as well as some items related to students' achievements. The third factor, named Community and explaining $4.1 \%$ of the variance, is made up of seven items reflecting sense of community concerning the brand. This factor is made up of items belonging to Brand love and Brand identification constructs. It refers to a psychological state of feeling and valuing his or her belonging to the HEl's brand. The fourth factor, Administrative staff (3.6\% of the variance), is formed by six items related to the willingness of administrative staff to provide support and their ability to offer a service which is adapted to the specific needs and requirements of each student. 
Table 2 - Factor analysis of university brand equity

\begin{tabular}{ll}
\hline Ability to solve students' problems & 0.752 \\
Ability to understand the needs of the & 0.75 \\
students & \\
Predisposition to offer help to students & 0.750 \\
Adequate assessment and grading methods & 0.721 \\
Individual attention to students & 0.709 \\
Fluid communication with students & 0.705 \\
Ability to deliver the unit programme & 0.702 \\
Qualification of teaching staff & 0.670 \\
Time it takes to return exams and & 0.660 \\
coursework & \\
Current teaching staff training & 0.650 \\
Quality of the learning materials & 0.622 \\
Delivers scheduled classes on time & 0.618 \\
Ability to use information technology to & 0.605
\end{tabular}

support student learning

If I was faced with the same choice again, Loyalty

I'd still choose UCLM

Overall, I am satisfied with my decision to 0.769

study at UCLM

I am satisfied with UCLM compared with my

0.760

ideal choice

I am satisfied with UCLM in terms of my

expectations

If anyone asks me for advice about

universities l'd recommend UCLM

I consider studying at UCLM a good

0.751

0.750

0.721

0.705

0.702

0.670

0.650

0.605

decision

If I had to do another course l'd consider

0.759

UCLM as the first option

The experience l'm gaining in this course

will be valuable for my professional career

When comparing the results with the

0.676

sacrifices made, my evaluation of studying

at UCLM is positive

When someone compliments UCLM it feels

\section{Community}

like a personal compliment

UCLM successes are my own successes

0.813

When someone criticizes UCLM, it feels like

0.791

a personal criticism

It bothers me If I see a story in the media

criticising UCLM

You are very interested in what others think

0.714

about UCLM

When you talk about UCLM, you usually say

0.711

'we' rather than 'they'

I feel a personal connection with UCLM

0.710

Time it takes to complete a task

Ability of admin staff to understand the

student needs

Individual attention when interacting with

students

Predisposition to provide support

0.517

Enrolment and transcript service

Administrative Staff

Ability of admin staff to fulfil their duties

0.833

0.831

0.830

0.814

0.719

0.691 
Table 2 - Factor analysis of university brand equity (Continued)

\begin{tabular}{|c|c|c|c|c|c|c|c|c|c|}
\hline & \multicolumn{9}{|c|}{ Study Programme } \\
\hline Employability services & - & - & - & - & 0.774 & - & - & - & - \\
\hline $\begin{array}{l}\text { Training opportunities in } \\
\text { companies/organizations }\end{array}$ & - & - & - & - & 0.769 & - & - & - & - \\
\hline $\begin{array}{l}\text { Postgraduate programs appropriate to } \\
\text { student needs }\end{array}$ & - & - & - & - & 0.759 & - & - & - & - \\
\hline International mobility & - & - & - & - & 0.714 & - & - & - & - \\
\hline Close to companies & - & - & - & - & 0.586 & - & - & - & - \\
\hline $\begin{array}{l}\text { Complementary training (seminars, } \\
\text { specialization courses...) }\end{array}$ & - & - & - & - & 0.537 & - & - & - & - \\
\hline \multirow[t]{2}{*}{$\begin{array}{l}\text { Availability of complementary services } \\
\text { (sports, culture, library) }\end{array}$} & - & - & - & - & 0.514 & - & - & - & - \\
\hline & & & \multicolumn{7}{|c|}{ Facilities and Equipment } \\
\hline Ease of access to buildings & - & - & - & - & - & 0.779 & - & - & - \\
\hline Campus buildings and facilities & - & - & - & - & - & 0.687 & - & - & - \\
\hline Location of the campus buildings & - & - & - & - & - & 0.634 & - & - & - \\
\hline Campus Virtual (intranet) & - & - & - & - & - & 0.601 & - & - & - \\
\hline Library resources & - & - & - & - & - & 0.558 & - & - & - \\
\hline \multirow[t]{2}{*}{ Teaching equipment on campus } & & & & & & 0.546 & & & \\
\hline & & & & & \multicolumn{5}{|c|}{ Brand Personality } \\
\hline Pleasant & - & - & - & - & - & - & 0.721 & - & - \\
\hline Dynamic & - & - & - & - & - & - & 0.684 & - & - \\
\hline Stimulating & - & - & - & - & - & - & 0.668 & - & - \\
\hline Happy & - & - & - & - & - & - & 0.667 & - & - \\
\hline Young & - & - & - & - & - & - & 0.618 & - & - \\
\hline \multicolumn{10}{|c|}{ Shared Values } \\
\hline UCLM values are similar to your values & - & - & - & - & - & - & - & 0.745 & - \\
\hline $\begin{array}{l}\text { UCLM values are compatible with the } \\
\text { things you think }\end{array}$ & - & - & - & - & - & - & - & 0.739 & - \\
\hline $\begin{array}{l}\text { UCLM values reflect the type of person you } \\
\text { are }\end{array}$ & - & - & - & - & - & - & - & 0.728 & - \\
\hline $\begin{array}{l}\text { The values of UCLM are consistent with } \\
\text { your own personal values }\end{array}$ & - & - & - & - & - & - & - & 0.702 & - \\
\hline \multicolumn{10}{|c|}{ Brand Trust } \\
\hline I can totally trust in UCLM & - & - & - & - & - & - & - & - & 0.685 \\
\hline $\begin{array}{l}\text { For me, UCLM is a sincere and honourable } \\
\text { institution }\end{array}$ & - & - & - & - & - & - & - & - & 0.671 \\
\hline $\begin{array}{l}\text { UCLM acts in an appropriate way in all } \\
\text { situations }\end{array}$ & - & - & - & - & - & - & - & - & 0.665 \\
\hline UCLM has a high level of integrity & - & - & - & - & - & - & - & - & 0.664 \\
\hline Percentaje of Variance Explained & $45.0 \%$ & $7.1 \%$ & $4.1 \%$ & $3.6 \%$ & $3.1 \%$ & $2.8 \%$ & $2.4 \%$ & $2.3 \%$ & $1.8 \%$ \\
\hline $\begin{array}{l}\text { Cronbach's } \\
\text { KMO }(\text { Kaiser-Meyer-Olkin })=0.973>0.5\end{array}$ & 0.959 & 0.933 & 0.898 & 0.949 & 0.909 & 0.871 & 0.936 & 0.956 & 0.950 \\
\hline
\end{tabular}

The fifth factor was labelled as Study programme (3.1\% of the variance) and is formed by seven items relating to the effectiveness of the study programme in responding to students' formative needs and maximizing employability opportunities. All the items related to the satisfaction with the university's facilities loaded on the sixth factor, which was labelled Facilities and equipment (2.8\% of the variance). The seventh factor was named as Brand personality $(2.4 \%$ of the variance) because it is formed by five items related to adjectives 
reflecting human characteristics associated to the university brand, as per Aaker (1997). The eighth factor, Shared Values (2.3\% of the variance), is formed by four items expressing shared values that students have with the university and its brand. The ninth and final factor, Brand trust (1.8\% of the variance), comprises four items related to the level of trust towards the institution.

\subsection{ANOVA. Testing disciplinary differences.}

ANOVA with Scheffé Test were conducted to assess whether there were statistically significant differences in brand equity perceptions across the three degrees (business, nursing and engineering). We considered brand dimensions as dependent variables and degree as independent variable. Following the analysis and before explaining the results obtained by the ANOVA, mean values were included in Table 3 with standard deviation values shown in brackets. These mean values are shown for each of the degree courses and for the entire sample. Broadly speaking, the mean values for all the factors vary between 4.0 and 7.15, suggesting that on average students showed intermediate levels of satisfaction. The ANOVA and Scheffé Test results suggest that most of the differences are between business and the other two courses, with few differences between nursing and engineering.

For the Teaching Staff factor, there are no differences in four of the thirteen items. With the exception of teaching quality, where Engineering students were more satisfied than Nursing students, Engineering and Nursing students hold similar levels of satisfaction. In contrast, Business students tend to show lower levels of satisfaction than, Engineering and Nursing students (reflected in codes 1 and 2 in Table 3). Engineering students rate the 'ability to solve their problems' and the 'predisposition to offer them help' more than others. They also value the 'individual attention', 'fluid communication', 'the qualification of teaching staff' and the 'time that it takes to return exams and coursework'. Nursing students tend to rate more than the others 'adequate assessment and grading methods', 'the ability of the teaching staff to deliver the unit programme' and 'scheduled classes on time'. In summary, it can be concluded that Engineering and Nursing students are more satisfied than Business students when it comes to teaching staff.

Nursing and Engineering students show similar levels of loyalty but there are more differences between them than when compared with Business students. It could be said that Nursing students are more loyal than Business and Engineering students, but in some cases Engineering students show greater levels of loyalty than Business students. In addition, in the case of the attitudinal and behavioural loyalty factor, differences exist between Business and the other two courses on all items, while there are no differences between Nursing and 
Engineering. Differences were found between Business and Engineering students in four of the nine statements that make up the factor.

Table 3 - University brand equity dimensions (means and differences across degrees)

\begin{tabular}{|c|c|c|c|c|c|c|}
\hline & & \multicolumn{4}{|c|}{ Mean (SD) } & \multirow{2}{*}{ Sig } \\
\hline & & Business & Nursing & Engineering & All & \\
\hline \multicolumn{7}{|c|}{ Teaching Staff (Variance: $45.0 \% ; \alpha=0.959$ ) } \\
\hline SQProf6 & & $5.16(2.26)$ & $5.59(2.47)$ & $5.64(2.37)$ & $5.45(2.37)$ & 2 \\
\hline SQProf5 & & $5.07(2.32)$ & $5.52(2.47)$ & $5.47(2.37)$ & $5.34(2.40)$ & n.s. \\
\hline SQProf11 & & $5.58(2.26)$ & $5.95(2.30)$ & $6.04(2.25)$ & $5.84(2.28)$ & 2 \\
\hline SQProf12 & & $5.05(2.38)$ & $5.81(2.30)$ & $5.60(2.32)$ & $5.46(2.36)$ & 1,2 \\
\hline SQProf4 & & $5.40(2.36)$ & $5.98(2.39)$ & $6.09(2.44)$ & $5.80(2.41)$ & 1,2 \\
\hline SQProf13 & & $5.38(2.20)$ & $5.85(2.41)$ & $5.97(2.22)$ & $5.70(2.29)$ & 1,2 \\
\hline SQProf7 & & $5.72(2.11)$ & $6.19(2.18)$ & $5.97(2.11)$ & $5.94(2.14)$ & 1 \\
\hline SQProf1 & & $5.77(2.37)$ & $5.87(2.48)$ & $6.39(2.35)$ & $6.00(2.41)$ & 2,3 \\
\hline SQProf10 & & $4.62(2.49)$ & $5.38(2.33)$ & $5.43(2.38)$ & $5.12(2.42)$ & 1,2 \\
\hline SQProf2 & & $5.45(2.31)$ & $5.45(2.65)$ & $5.79(2.47)$ & $5.56(2.47)$ & n.s. \\
\hline SQProf8 & & $5.74(2.11)$ & $5.79(2.35)$ & $5.84(2.19)$ & $5.79(2.21)$ & n.s. \\
\hline SQProf9 & & $6.16(2.36)$ & $6.74(2.21)$ & $6.72(2.46)$ & $6.52(2.29)$ & 1,2 \\
\hline SQProf3 & & $5.91(2.12)$ & $6.03(2.42)$ & $5.98(2.38)$ & $5.97(2.30)$ & n.s. \\
\hline All items & - & $5.46(1.89)$ & $5.86(1.96)$ & $5.92(1.90)$ & $5.73(1.92)$ & 1,2 \\
\hline \multicolumn{7}{|c|}{ Attitudinal \& behavioral loyalty (Variance: 7.1\%; $\alpha=0.933$ ) } \\
\hline Loyal1 & & $4.84(2.65)$ & $5.50(2.86)$ & $5.36(2.70)$ & $5.21(2.75)$ & 1 \\
\hline Sat3 & & $6.24(2.12)$ & $6.70(2.26)$ & $6.59(2.04)$ & $6.49(2.14)$ & 1 \\
\hline Sat1 & & $6.48(2.08)$ & $6.99(2.15)$ & $6.89(2.08)$ & $6.77(2.11)$ & 1,2 \\
\hline Sat2 & & $5.95(2.17)$ & $6.44(2.17)$ & $6.26(1.97)$ & $6.20(2.11)$ & 1 \\
\hline Loyal3 & & $4.92(2.39)$ & $5.38(2.62)$ & $5.58(2.34)$ & $5.27(2.46)$ & 1,2 \\
\hline PValue2 & & $6.24(2.30)$ & $6,85(2.52)$ & $6.68(2.40)$ & $6.57(2.41)$ & 1,2 \\
\hline Loyal2 & & $4.58(2.64)$ & $5.13(2.87)$ & $4.79(2.68)$ & $4.81(2.73)$ & 1 \\
\hline PValue4 & & $6.25(2.24)$ & $7.15(2.24)$ & $7.14(2.28)$ & $6.81(2.29)$ & 1,2 \\
\hline PValue3 & & $5.44(2.39)$ & $5.96(2.49)$ & $5.71(2.43)$ & $5.68(2.44)$ & 1 \\
\hline All items & - & $5.66(1.89)$ & $6.23(2.00)$ & $6.11(1.87)$ & $5.98(1.93)$ & 1,2 \\
\hline \multicolumn{7}{|c|}{ Community (Variance: $4.1 \% ; \alpha=0.898$ ) } \\
\hline Community5 & & $4.50(2.37)$ & $4.27(2.59)$ & $4.56(2.45)$ & $4.45(2.46)$ & n.s. \\
\hline Community4 & & $4.19(2.25)$ & $4.23(2.64)$ & $4.64(2.49)$ & $4.35(2.46)$ & 2 \\
\hline Community1 & & $4.07(2.48)$ & $4.00(2.70)$ & $4.26(2.67)$ & $4.11(2.62)$ & n.s. \\
\hline Community 6 & & $4.98(2.53)$ & $5.16(2.63)$ & $5.30(2.63)$ & $5.14(2.60)$ & n.s. \\
\hline Community2 & & $5.44(2.44)$ & $5.32(2.69)$ & $5.66(2.49)$ & $5.47(2.53)$ & n.s. \\
\hline Community3 & & $4.57(2.60)$ & $4.68(3.00)$ & $4.78(2.66)$ & $4.67(2.74)$ & n.s. \\
\hline BLove3 & & $4.71(2.31)$ & $4.84(2.46)$ & $5.31(2.30)$ & $4.95(2.37)$ & 2,3 \\
\hline All items & - & $4.64(1.87)$ & $4.64(2.19)$ & $4.93(1.95)$ & $4.73(2.00)$ & n.s. \\
\hline \multicolumn{7}{|c|}{ Admin Staff (Variance: $3.6 \% ; \alpha=0.949$ ) } \\
\hline SQAdm4 & & $5.61(2.06)$ & $5.90(2.11)$ & $5.69(2.04)$ & $5.72(2.07)$ & n.s. \\
\hline SQAdm2 & & $5.72(2.09)$ & $6.11(2.15)$ & $5.95(2.11)$ & $5.91(2.12)$ & 1 \\
\hline SQAdm3 & & $5.69(2.05)$ & $6.03(2.08)$ & $5.83(1.98)$ & $5.84(2.04)$ & n.s. \\
\hline SQAdm6 & & $5.62(2.15)$ & $6.00(2.16)$ & $5.78(2.22)$ & $5.79(2.18)$ & n.s. \\
\hline SQAdm5 & & $5.68(2.29)$ & $6.14(2.17)$ & $5.98(2.33)$ & $5.92(2.27)$ & 1 \\
\hline SQAdm1 & & $6.05(2.01)$ & $6.57(2.02)$ & $6.23(2.19)$ & $6.26(2.11)$ & 1 \\
\hline All items & - & $5.73(1.91)$ & $6.13(1.87)$ & $5.91(1.91)$ & $5.91(1.90)$ & 1 \\
\hline \multicolumn{7}{|c|}{ Study Programme (Variance: 3.1\%; $\alpha=0.909$ ) } \\
\hline SQStudy6 & & $5.51(2.19)$ & $4.92(2.39)$ & $5.27(2.20)$ & $5.25(2.27)$ & 1 \\
\hline SQStudy3 & & $5.83(2.29)$ & $5.41(2.54)$ & $5.52(2.44)$ & $5.60(2.42)$ & n.s. \\
\hline SQStudy4 & & $5.62(2.11)$ & $5.36(2.36)$ & $5.10(2.46)$ & $5.37(2.31)$ & 2 \\
\hline SQStudy5 & & $5.98(2.18)$ & $5.94(2.30)$ & $5.73(2.21)$ & $5.88(2.23)$ & n.s. \\
\hline Focus4 & & 5.96 (1.99) & $5.62(2.31)$ & $5.95(2.26)$ & $5.86(2.18)$ & n.s. \\
\hline SQStudy2 & & $6.28(2.11)$ & $6.15(2.30)$ & $5.87(2.14)$ & $6.11(2.18)$ & 2 \\
\hline SQStudy7 & & $6.36(2.18)$ & $6.49(2.12)$ & $6.37(2.24)$ & $6.40(2.18)$ & n.s. \\
\hline All items & - & $5.93(1.78)$ & $5.70(1.84)$ & $5.69(1.82)$ & $5.78(1.81)$ & n.s. \\
\hline
\end{tabular}

Notes: Sig - ANOVA with Scheffé Test at the 0.05 level; n.s. - non-significant; Numbers indicate Statistical difference between groups (1 - Business vs. Nursing; 2 - Business vs. Engineering; 3 - Nursing vs. Engineering) 
Table 3 - University brand equity dimensions (means and differences across degrees) (continued)

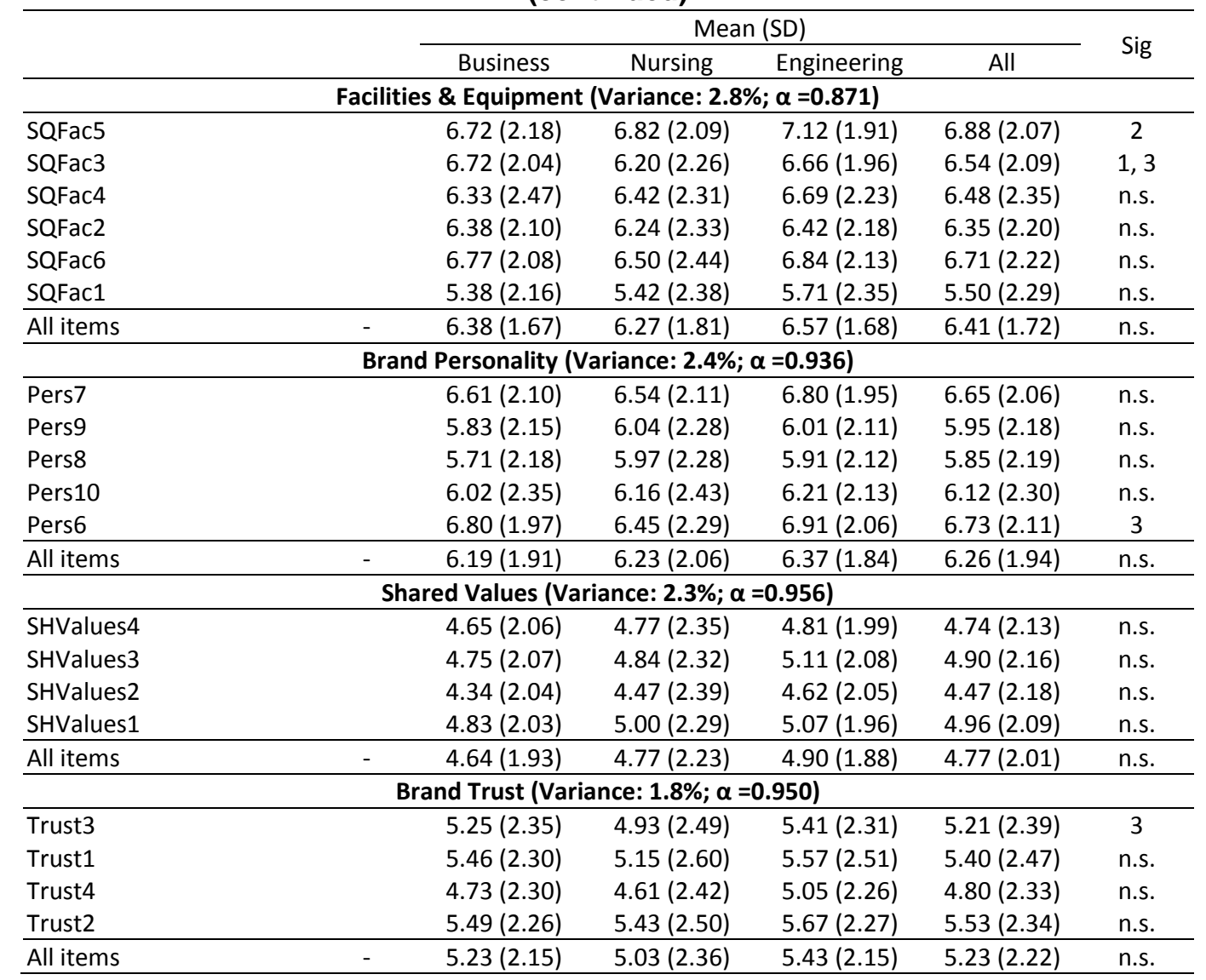

Notes: Sig - ANOVA with Scheffé Test at the 0.05 level; n.s. - non-significant; Numbers indicate Statistical difference between groups (1 - Business vs. Nursing; 2 - Business vs. Engineering; 3 - Nursing vs. Engineering)

In a more specific analysis, it can be suggested that Nursing students would be more prone to study at UCLM if they were to make such decision again. They present higher scores than the other two groups in terms of their expectations and the "possibility to keep on studying another course at UCLM'. They have also given a higher score to 'studying at the UCLM has contributed to my professional career', while also rating positive the statement about the sacrifices they made. Engineering students tend to rate the statement 'giving advice and recommending UCLM to someone else' higher than the others.

The Community factor was found to have no differences between degrees with the exception of the personal connection and the university success questions that showed differences between Business and Engineering. Engineers tend to show a greater personal connection with the brand love item 'I feel a personal connection with UCLM' and also with the community item 'UCLM successes are my own successes'. On the whole, the mean values for the community items were among the lowest within the scale.

With regards to the mean values for Administrative staff, Nursing students are more satisfied that Business and Engineering students. They rate the statements 'ability of administrative 
staff to understand the student's needs' and 'the enrolment and transcript service and the ability of the administrative staff to fulfil their duties' more than the other two.

For the Study Programme, differences were found when comparing Business and Nursing with the latter being less satisfied. In addition, differences can be found between Business and Engineering students with the latter revealing lower levels of satisfaction than the former. Thus, it can be concluded that Business students are more satisfied than the others as they significantly rated the following items higher: 'employability services', 'postgraduate programs appropriate to student's needs' and 'complementary training (seminars, specialization courses...)'.

With regard to Facilities and Equipment, only two differences were found. Business students were more satisfied with buildings and facilities compared to Nurses, while Engineering students were more satisfied than Nursing with regard to buildings and facilities and 'ease of access to buildings'. For Brand Personality, differences were found between Nursing and Engineering degrees, with Engineering students associating the university with the adjective 'young' more than their Nursing counterparts.

No differences were found for Shared Values. A look at the mean values suggests that students of the three degrees perceived the University as performing medium to low on all items measuring these brand equity construct (mean values rarely exceeding 5 ). Finally, only one difference was found with regards to Brand Trust. Nursing students considered the University to perform lower in terms of honour and integrity when compared to engineering students.

In summary, based on Keller's (1993) pyramid, differences appear to be more at the performance (teaching staff) and resonance (loyalty) levels, with fewer differences in the other dimensions. The majority of the differences are between Business and Nursing, with a smaller number of differences between Business and Engineering. Only a handful of items were evaluated differently between nursing and engineering.

\subsection{Logistic regression. Modelling loyalty.}

In order to test hypothesis 2 we examined which brand equity components determine student's loyalty using logistic regression. The model was estimated for the entire sample and the three degrees. In this study, logistic regression predicts which of the two categories (moderate-low and high loyalty) a student is likely to belong to given their perceptions of the university's brand equity dimension. As shown in Table 4, the final classification percentages were above $80 \%$, which is a substantial increase on the correct classification with the 
constant model. In addition, the model's $X^{2}$ coefficients showed significant levels leading to a decrease in the log-likelihood values when the 8 determinants were added. The Nagelkerke's value (a pseudo $\mathrm{R}^{2}$ ) of 0.540 indicates that the 8 determinants accounted for $54.0 \%$ of the variance in loyalty for the whole sample. As for each individual course, the 8 predictors explained the higher variance in Engineering (61.0\%), following by (57.3\%) and Business (48.7\%). Taken together, these results show that the models for both the entire sample and for each course show a good fit to the data, thus making logistic regression suitable.

Table 4 - Characteristics of the loyalty models

\begin{tabular}{lrrrr}
\hline & $\begin{array}{r}\text { All students } \\
(\mathrm{N}=1039)\end{array}$ & $\begin{array}{r}\text { Business } \\
(\mathrm{N}=383)\end{array}$ & $\begin{array}{r}\text { Nursing } \\
(\mathrm{N}=316)\end{array}$ & $\begin{array}{r}\text { Engineering } \\
(\mathrm{N}=340)\end{array}$ \\
\hline Initial -2 Log likelihood $(\mathrm{X} 2)$ & 1.398 .8 & 490.7 & 436.2 & 460.7 \\
Final -2 Log likelihood $(\mathrm{X} 2)$ & 868.9 & 324.9 & 259.1 & 255.6 \\
\hline Nagelkerke R2 & 0.540 & 0.487 & 0.573 & 0.610 \\
\hline Initial classification group & $60.0 \%$ & $66.1 \%$ & $53.8 \%$ & $58.8 \%$ \\
Moderate low loyalty & $100.0 \%$ & $100.0 \%$ & $100.0 \%$ & $100.0 \%$ \\
High loyalty & $0.0 \%$ & $0.0 \%$ & $0.0 \%$ & $0.0 \%$ \\
\hline Final classification group & $81.7 \%$ & $87.4 \%$ & $81.0 \%$ & $83.5 \%$ \\
Moderate low loyalty & $85.1 \%$ & $67.7 \%$ & $80.6 \%$ & $85.0 \%$ \\
High loyalty & $76.7 \%$ & $80.7 \%$ & $81.5 \%$ & $81.4 \%$ \\
\hline Model coefficient $(\mathrm{X} 2)$ & 529.6 & 165.8 & 177.1 & 205.1 \\
& $(\mathrm{Df}=8 ; p<0.05)$ & $(\mathrm{Df}=8 ; p<0.05)$ & $(\mathrm{Df}=8 ; p<0.05)$ & $(\mathrm{Df}=8 ; p<0.05)$ \\
\hline
\end{tabular}

The parameter estimates of the logistic regression analysis are shown in Table 5. Employing a 0.05 criterion of statistical significance, all but one determinant (administrative staff and services) had an effect on the level of loyalty. Three determinants were statistically significant for the three course groups: brand community, brand personality and brand trust. Facilities and equipment was significant for the whole sample but not when individual courses were analysed.

For the sample as a whole, teaching staff was the most important determinant as shown by the highest odds ratio (1.738). This means that when holding all other variables constant, an increase of one quintile in the quality of teaching staff increases 1.7 times the likelihood of that student becoming loyal. The second and third most important determinants were brand personality $(\operatorname{Exp}(B)=1.640)$ and brand trust $(\operatorname{Exp}(B)=1.532)$, respectively. For Business students, the study programme had the most significant effect on loyalty with an odds ratio of 1.781 , followed by teaching staff $(\operatorname{Exp}(B)=1.675)$ and brand personality $(\operatorname{Exp}(B)=1.647)$. With regards to Nursing, only three determinants had a significant influence on loyalty: brand personality $(\operatorname{Exp}(B)=1.858)$, brand community $(\operatorname{Exp}(B)=1.713)$ and brand trust $(\operatorname{Exp}(B)=1.628)$. Finally, the most influential determinant on the loyalty of Engineering students was the quality of teaching staff with an odds ratio of 2.260. This means that an increase of one quintile in the quality of teaching staff increases 2.2 times the likelihood of an Engineering student being loyal. 
Table 5 - Loyalty models parameters

\begin{tabular}{lccccccccc} 
& \multicolumn{2}{c}{ All students } & \multicolumn{2}{c}{ Business } & \multicolumn{2}{c}{ Nursing } & \multicolumn{3}{c}{ Engineering } \\
\cline { 2 - 11 } & $\mathrm{p}$ & $\operatorname{Exp}(B)$ & $\mathrm{p}$ & $\operatorname{Exp}(B)$ & $\mathrm{p}$ & $\operatorname{Exp}(B)$ & $\mathrm{P}$ & $\operatorname{Exp}(B)$ \\
\hline Teaching staff & $\mathbf{0 . 0 0 0}$ & $\mathbf{1 . 7 3 8}$ & $\mathbf{0 . 0 1 0}$ & $\mathbf{1 . 6 7 5}$ & 0.413 & 1.245 & $\mathbf{0 . 0 0 1}$ & $\mathbf{2 . 2 6 0}$ \\
Community & $\mathbf{0 . 0 0 0}$ & $\mathbf{1 . 5 0 2}$ & & $\mathbf{0 . 0 3 0}$ & $\mathbf{1 . 4 1 2}$ & $\mathbf{0 . 0 0 2}$ & $\mathbf{1 . 7 1 3}$ & $\mathbf{0 . 0 4 2}$ & $\mathbf{1 . 4 2 2}$ \\
Administrative staff and services & 0.174 & 0.861 & & 0.117 & 0.750 & 0.652 & 1.102 & 0.090 & 0.708 \\
Study programme & $\mathbf{0 . 0 0 2}$ & $\mathbf{1 . 4 3 7}$ & & $\mathbf{0 . 0 0 5}$ & $\mathbf{1 . 7 8 1}$ & 0.326 & 1.241 & $\mathbf{0 . 0 1 9}$ & $\mathbf{1 . 6 1 4}$ \\
Facilities and equipment & $\mathbf{0 . 0 3 2}$ & $\mathbf{1 . 2 8 8}$ & & 0.555 & 1.125 & 0.172 & 1.340 & 0.060 & 1.552 \\
Brand personality & $\mathbf{0 . 0 0 0}$ & $\mathbf{1 . 6 4 0}$ & & $\mathbf{0 . 0 1 4}$ & $\mathbf{1 . 6 4 7}$ & $\mathbf{0 . 0 0 8}$ & $\mathbf{1 . 8 5 8}$ & $\mathbf{0 . 0 2 8}$ & $\mathbf{1 . 6 9 0}$ \\
Shared values & $\mathbf{0 . 0 1 4}$ & $\mathbf{1 . 3 0 8}$ & & 0.278 & 1.227 & 0.571 & 1.112 & $\mathbf{0 . 0 1 6}$ & $\mathbf{1 . 6 8 0}$ \\
Brand trust & $\mathbf{0 . 0 0 0}$ & $\mathbf{1 . 5 3 2}$ & & $\mathbf{0 . 0 2 8}$ & $\mathbf{1 . 5 0 7}$ & $\mathbf{0 . 0 0 6}$ & $\mathbf{1 . 6 2 8}$ & $\mathbf{0 . 0 0 3}$ & $\mathbf{1 . 7 4 1}$ \\
\hline
\end{tabular}

\section{CONCLUSIONS}

Some important implications emerge from the findings. First, understanding how students evaluate universities from a branding perspective is critical for enhancing overall student satisfaction and loyalty. The analyses carried out indicated that there are differences between groups. Business, Nursing and Engineering do not reveal similar levels when applying a Brand Equity scale to the satisfaction with their university experience. However, differences are not consistent in statistical terms because they depend on the dimensions being evaluated. Differences in student judgements across groups were mainly found at the performance and resonance levels.

Quality of teaching was a well rated factor by the Nursing and Engineering students who tend to be equally satisfied, and more so than Business students. Engineering students scored higher than the others on the staff's ability to solve their problems and the predisposition on the part of the teaching staff to offer them help. Nursing students valued the qualifications of teaching staff regarding the adequacy of their methodology. Nursing and Engineering students were more loyal to the university than Business students, reflected in a greater likelihood to enrol for other study programmes offered by the university. Engineering students showed higher levels of sense of community, trusting the faculty more than the other two groups. The administrative staff statements were more highly evaluated by Nursing students. On the other hand, Business students felt more satisfied with their study programme. University facilities and equipment were more highly rated by engineering students, and they were more satisfied with the employability services, postgraduate programs and the complementary training offered by the University. Few, if any differences, were found for brand personality and shared values.

Second, retention strategies should consider emphasizing different aspect of the educational experience as given by the brand dimensions. While only three of the eight determinants 
influenced the loyalty of Nursing students (community, personality and trust), a larger number of determinants predicted the level of loyalty of business (teaching staff, community, study programme, personality and trust) and engineering students (teaching staff, community, study programme, brand personality, shared values and trust). The most important contributors to level of loyalty varied across student groups: study programme for business, personality for nursing and teaching staff for engineering students. Programme administration staff and services was the only factor not determining level of loyalty when the entire sample was taken in to consideration, and neither determined the level of loyalty of each individual course.

Results are consistent with several studies that describe typical characteristics and related teaching and learning approaches adopted by different discipline groups. In general, hard pure disciplines tend to be more knowledge-driven, content-focused, cumulative, quantitative and "teacher-centred" (Lattuca and Stark, 1995; Neumann et al, 2002; Lindblom-Ylänne et al, 2006), whereas soft disciplines are rich in language, and tend to adopt a more interpretive, critical and "student-centred" approaches (Jessop and Maleckar, 2016). Moreover, Pinar et al (2011) conclude that the delivery process for the school education could be more important than what is delivered.

Some epistemological differences can be used as an explanation for disparities in ratings and approaches to teaching between hard and soft disciplines (Kember and Leung, 2011). Teachers in hard disciplines have been found to be more likely to have a teachers-centred conception of teaching (Lindblom-Ylänne et al, 2006). The business administration group had the lowest rates for teaching, which presumably indicates students' perception of this dimension is less strong. This might be interpreted as meaning that business administration discipline set a relatively high proportion of learning activities, such us group projects, practice works that involves the development of intellectual capacities via direct impact, as is demonstrated by Kember and Leung (2011).

According to the differences shown above, adopting an umbrella branding approach is a consideration that must be taken carefully. Therefore, HEl's managers should take into account differences of opinion on the importance of marketing, branding and communications among the stakeholders (deans, professors, staff and students) about having a unified image (Celly and Knepper, 2010). 


\subsection{Implications for practice and research}

This research compares three university degrees with different scientific and technological qualifications and skills. The providers of education services must take into account the loyalty of existing students as they could recommend the institution to others or continue their studies with another course at the same institution. As shown in this investigation, students demonstrate different levels of satisfaction, trust and loyalty depending on the degree course they are taking. Thus, using a specific communication strategy for each degree could be a more efficient way of increasing the global perception of the university image, rather than using integrated institutional communication strategies.

This study highlights relevant issues for marketing management in several ways. It is worthwhile to determine how satisfied students are and how they assess the university and its services. More specific, any brand strategy development requires a deep knowledge of disciplinary/degree differences and a more focused approach. Once it is known how well customers rate a service and which valuation criteria are more relevant, it is possible to build effective marketing actions centred on improving consumer's brand evaluations. Thus, university leaders must develop an appreciation of educational needs, designing and offering appropriate courses to meet these needs to differentiate from competing universities. By creating such awareness in their target student populations, university leaders will be better position to persuade them to include the university in their consideration set (Celly and Knepper, 2010). As stated by Chapleo (2007), public universities have smaller budgets for advertising and so they must focus on other elements of the marketing mix considering the role of branding.

Moreover, HE marketers should realize that developing a positive brand image dimension of brand equity is more complex than simply expanding their promotional campaigns. HEls aiming to improve how satisfied their students are, should pay attention on the course delivery aspects of the educational service by carefully selecting appropriate teaching staff and defining good educational objectives and programmes (García-Aracil, 2009). Similarly, brands must be able of implementing mechanisms, processes and platforms that enable consumers and other stakeholders to provide their views, suggestions and ideas (Iglesias et al, 2013).

Educators should understand that a good relationship with the students implies positive consequences for all the stakeholders involved with the Higher Education institution. Furthermore, teaching staff, being one of the main university stakeholders, must be encouraged by the institution to foster these good relations. It would be interesting to 
encourage quality assessments of their teaching activity on a regular basis. Teaching staff have ongoing direct contact with students and are therefore the key actors responsible for guiding students through their university course. In addition, in order to improve their university branding, leaders must examine university communication material, whether print or digital with a view to identify possible causes of confusion and options for action.

Positioning the brand requires identifying the key strengths of a brand's identity and, in multicampus cases as in this study, a brand communication approach should integrate all the campuses while at the same time pursue a different and meaningful communication with each campus due to their particularities (different staff, different physical resources). Consequently, university brands must be an umbrella that unifies all campuses, building a persuasive argument based on responses from the various constituents of the brand architecture (Celly and Knepper, 2010). This support must be based on an assessment of costs to reach continuity in terms of differentiation of visual identity from competitors, flexibility and adaptability of the communication set employed. Celly and Knepper (2010) also highlight the fact that moving towards an umbrella brand requires a consensus about the value and the visual identity for each campus and the University as a whole. A good practice to enhance this could be building positive associations and increasing the credibility and visibility of the university brand across the institution.

\subsection{Limitations}

The survey took place at four different cities from the Castilla La Mancha region where UCLM is established. It could be also interesting to carry out the survey at different types of HEls and examine possible cross-cultural differences to enhance the generalizability of the findings. In fact, results may differ in a university with a different history and standing. Another issue is whether better measurements for some items might improve the quality of the research. Finally, only three degree courses have been analysed. It would be useful to replicate the survey for other degree courses offered by the university.

\subsection{Recommendation for further research}

Some authors emphasize the relevance of studying the connection between degrees and fields of study at undergraduate degree level (Becker and Toutkoushian, 2013). In terms of improving this study, a study could be carried out to measure levels of satisfaction between students in Master's and Doctor's degrees in terms of perception with the university brand. These students interact with the brand differently and their motivations differ from 
undergraduate students. Further research could consider other branding-related variables and other stakeholders (such as administrative staff or teaching staff). 


\section{REFERENCES}

Aaker, D.A. (1991) Managing Brand Equity. New York: The Free Press.

Aaker, J.L. (1997) Dimensions of brand personality. Journal of Marketing Research 34(3): 347-356.

Albert, N., Merunka, D. and Valette-Florence, P. (2013) Brand passion: Antecedents and consequences. Journal of Business Research 66(7): 904-909.

Alessandri, S.W., Yang, S.U. and Kinsey, D.F. (2006) An integrative approach to university visual identity and reputation. Corporate Reputation Review 9(4): 258-270.

Alves, H. (2011) The measurement of perceived value in higher education: a unidimensional approach. The Service Industries Journal 31(12): 1943-1960.

Andaleeb, S.S. (1996) An experimental investigation of satisfaction and commitment in marketing channels: The role of trust and dependence. Journal of Retailing 72(1): 77-93.

Anderson, J.C. and Narus, J.A. (1990) A model of distributor firm and manufacturer firm working partnerships. Journal of Marketing 54(1): 42-58.

Argenti, P. and Druckenmiller, B. (2004) Reputation and the corporate brand. Corporate Reputation Review 6(4): 368-374.

Arpan, L.M., Raney, A.A. and Zivnuska, S. (2003) A cognitive approach to understanding university image. Corporate Communications: An International Journal 8(2): 97-113.

Asaad, Y., Melewar, T. C. and Cohen, G. (2014) Export market orientation in universities: Bridging the gap between export marketing and higher education. The Marketing Review 14(2): 145-162.

Asaad, Y., Melewar, T.C., Cohen, G. and Balmer, J. (2013) Universities and export market orientation: An exploratory study of UK post-92 universities. Marketing Intelligence and Planning 31(7): 838-856.

Athiyaman, A. (1997) Linking student satisfaction and service quality perceptions: the case of university education. European Journal of Marketing 31(7): 528-540.

Balaji, M.S., Roy, S.K. and Sadeque, S. (2016) Antecedents and consequences of university brand identification. Journal of Business Research 69(8): 3023-3032.

Balmer, J.M. and Liao, M.N. (2007) Student corporate brand identification: an exploratory case study. Corporate Communications: An International Journal 12(4): 356-375.

Barnes, L., Bull, K., Campbell, N. and Perry, K. (2001) Effects of academic discipline and teaching goals in predicting grading beliefs among undergraduate teaching faculty. Research in Higher Education 42(4): 455467.

Bartz, A.E. (1999) Basic statistical concepts. Macmillan Publishing Co., Inc.

Batra, R., Ahuvia, A. and Bagozzi, R.P. (2012) Brand love. Journal of Marketing 76(2): 1-16.

Becher, T. (1987) The disciplinary shaping of the profesion. In: B.R. Clark (ed.) The Academic Profession: National, Disciplinary and Institutional Settings. Berkeley: University of California Press, pp. 271-303.

Becher, T. (1994) The significance of disciplinary differences. Studies in Higher education 19(2): 151-161.

Becker, W.E., and Toutkoushian, R.K. (2013) On the meaning of markets in higher education. In: Higher education: Handbook of theory and research. Springer Netherlands, pp. 323-376.

Beerli, A., Díaz, G. and Pérez, P.J. (2002) The configuration of the university image and its relationship with the satisfaction of students. Journal of Educational administration 40(5): 486-505.

Bergkvist, L. and Bech-Larsen, T. (2010) Two studies of consequences and actionable antecedents of brand love. Journal of Brand Management 17(7): 504-518.

Biglan, A. (1973a) Relationships between subject matter characteristics and the structure and output of university departments. Journal of Applied Psychology 57(3): 204-213.

Biglan, A. (1973b) The characteristics of subject matter in different scientific areas. Journal of Applied Psychology 57(3): 195-203.

Blackston, M. (1993) Beyond brand personality: building brand relationships. In D.A. Aaker and A. Biel (eds.) Brand equity and advertising: Advertising's role in building strong brands. Psychology Press, pp. 113-124.

Borden, V.M. (1995) Segmenting student markets with a student satisfaction and priorities survey. Research in Higher Education 36(1): 73-88.

Braxton, J.M. (1995) Disciplines with and affinity for the improvement of undergraduate education. In: N. Hativa and M. Marincovich, (eds.) Disciplinary Differences in teaching and learning: Implications for practice. San Francisco, Jossey-Bass, pp. 59-64.

Bulotaite, N (2003) University Heritage - An Institutional Tool for Branding and Marketing. Higher Education in Europe 28(4): 449-454.

Celly, K.S. and Knepper, B. (2010) The California State University: A case on branding the largest public university system in the US. International Journal of Nonprofit and Voluntary Sector Marketing 15(2): 137156.

Chang, C.K. and Fong, E.T. (2018) Disciplinary differences and implications for the development of generic skills: a study of engineering and business students' perceptions of generic skills. European Journal of Engineering Education 43(6): 927-949.

Chapleo, C. (2007) Barriers to brand building in UK universities?. International Journal of Nonprofit and Voluntary Sector Marketing 12(1): 23-32.

Chaudhuri, A. (2002) How brand reputation affects the advertising-brand equity link. Journal of Advertising Research 42(3): 33-43.

Chen, Y.F. and Hsiao, C.H. (2009) Applying market segmentation theory to student behaviour in selecting a school or department. New Horizons in Education 57(2): 32-43. 
Coughlan, T. and Perryman, L.A. (2011) Something for everyone?. The different approaches of academic disciplines to open educational resources and the effect of widening participation. Journal of Open, Flexible and Distance Learning 15(2): 11-27.

Cronin, J.J. and Taylor, S.A. (1992) Measuring service quality: a reexamination and extension. Journal of marketing 56(3): 55-68.

D'Astous, A. and Boujbel, L. (2007) Positioning countries on personality dimensions: Scale development and implications for country marketing. Journal of Business Research 60(3): 231-239.

Delaney, A.M. (2001) Assessing undergraduate education from graduating seniors' perspective: Peer institutions provide the context. Tertiary Education and Management 7(3): 255-276.

Dennis, C., Papagiannidis, S., Alamanos, E. and Bourlakis, M. (2016) The role of brand attachment strength in higher education. Journal of Business Research 69(8): 3049-3057.

Denson, N., Loveday, T. and Dalton, H. (2010) Student evaluation of courses: what predicts satisfaction?. Higher Education Research and Development 29(4): 339-356.

Dholakia, R.R. and Acciardo, L.A. (2014) Branding a state university: Doing it right. Journal of Marketing for Higher Education 24(1): 144-163.

Dion, P.A., Javalgi, R. and Dilorenzo-Aiss, J. (1998) An empirical assessment of the Zeithaml, Berry and Parasuraman service expectations model. Service Industries Journal 18(4): 66-86.

Douglas, J., McClelland, R. and Davies, J. (2008) The development of a conceptual model of student satisfaction with their experience in higher education. Quality assurance in education 16(1): 19-35.

Eagle, L. and Brennan, R. (2007) Are students customers? TQM and marketing perspectives. Quality assurance in education 15(1): 44-60.

Eakuru, N. and Mat, N.K.N. (2008) The application of structural equation modelling (SEM) in determining the antecedents of customer loyalty in banks in South Thailand. The Business Review, Cambridge 10(2): 129139.

Elliott, K.M. and Healy, M.A. (2001) Key factors influencing student satisfaction related to recruitment and retention. Journal of Marketing for Higher Education 10(4): 1-11.

Faham, E., Rezvanfar, A., Mohammadi, S.H.M. and Nohooji, M.R. (2017) Using system dynamics to develop education for sustainable development in higher education with the emphasis on the sustainability competencies of students. Technological Forecasting and Social Change, 123: 307-326.

Foroudi, P., Yu, Q., Gupta, S. and Foroudi, M. M. (2019) Enhancing university brand image and reputation through customer value co-creation behaviour. Technological Forecasting and Social Change 138: 218-227.

García-Aracil, A. (2009) European graduates' level of satisfaction with higher education. Higher Education 57(1): 1.

Garbarino, E. and Johnson, M.S. (1999) The different roles of satisfaction, trust, and commitment in customer relationships. Journal of Marketing 63(2): 70-87.

Grace, D., Weaven, S., Bodey, K., Ross, M. and Weaven, K. (2012) Putting student evaluations into perspective: The course experience quality and satisfaction model (CEQS). Studies in Educational Evaluation 38(2): 3543.

Hair, J.F., Anderson, R.E., Tatham, R.L. and Black, W.C. (1998) Multivariate data analysis. New Jersey, USA: Prentice Hall.

Harvey, L. (1995) Keeping the customer satisfied: the student satisfaction approach. IEE Colloquium on 'Quality in Higher Education', pp. 8-19.

Hemsley-Brown, J.V. and Goonawardana, S. (2007) Brand harmonization in the international higher education market. Journal of Business Research 60(9): 942-948.

Hemsley-Brown, J.V. and Oplatka, I. (2006) Universities in a competitive marketplace - A systematic review of the literature on higher education marketing. International Journal of Public Sector Management 19(4): 316338.

Heiland, D. and Rosenthal, L.J. (2011) Literaty study, measurement and the sublime: Disciplinary assessment. New York, NY: Teagle Foundations.

Hill, F.M. (1995) Managing service quality in higher education: the role of the student as primary consumer. Quality assurance in education 3(3): 10-21.

Iglesias, O., Ind, N. and Alfaro, M. (2013) The organic view of the brand: A brand value co-creation model. Journal of Brand Management 20(8): 670-688.

Iqbal, M.J., Rasli, A.B.M. and Hassan, I. (2012) University branding: A myth or a reality. Pakistan journal of commerce and social sciences 6(1): 168-184.

Ivy, J. (2001) Higher education institution image: a correspondence analysis approach. International Journal of Education Management 15(6/7): 276-82.

Ivy, J. (2008) A new higher education marketing mix: The 7Ps for MBA marketing. International Journal of Educational Management 22(4): 288-299.

Joseph, M., Yakhou, M. and Stone, G. (2005) An educational institution's quest for service quality: customers' perspective. Quality Assurance in Education 13(1): 66-82.

Jessop, T. and Maleckar, B. (2016) The influence of disciplinary assessment patterns on student learning: a comparative study. Studies in Higher Education 41(4): 696-711.

Keller, K.L. (1993) Conceptualizing, measuring and managing customer based brand equity. Journal of Marketing 57(1): 1-22.

Keller, K.L. (2001) Building customer-based brand equity. Marketing Management 10(7/8): 15-19. 
Keller, K.L. (2007) Strategic Brand Management: Building, Measuring and Managing Brand Equity. New Jersey: Prentice Hall.

Kember, D. and Leung, D.Y.P. (2011) Disciplinary differences in student ratings of teaching quality. Research in Higher Education 52(3): 278-299.

Kemp, B. and Jones, C. (2007) Academic use of digital resources: Disciplinary differences and the issue of progression revisited. Educational Technology and Society 10(1): 52-60.

Kuh, G.D., Ikenberry, S.O., Jankowski, N.A., Cain, T.R., Ewell, P.T., Hutchings, P. and Kinzie, J. (2015) Using evidence of student learning to improve higher education. San Francisco, CA: Jossey-Bass.

La Rocca, M., Parrella, M. L., Primerano, I., Sulis, I. and Vitale, M. P. (2017) An integrated strategy for the analysis of student evaluation of teaching: from descriptive measures to explanatory models. Quality and Quantity 51(2): 675-691.

Lam, S.Y., Shankar, V., Erramilli, M.K. and Murthy, B. (2004) Customer value, satisfaction, loyalty, and switching costs: an illustration from a business-to-business service context. Journal of the Academy of Marketing Science 32(3): 293-311.

Landrum, R.E., Turrisi, R. and Harless, C. (1998) University image: the benefits of assessment and modelling. Journal of Marketing Higher Education 9: 53-68.

Lattuca, L.R. and Stark, J.S. (1995) Modifying the major: discretionary thoughts from ten disciplines. Review of Higher Education 18(2): 315-344.

LeBlanc, G. and Nguyen, N. (1997) Searching for excellence in business education: an exploratory study of customer impressions of service quality. International Journal of Educational Management 11(2): 72-79.

Lee, H., Lee, Y. and Yoo, D. (2000) The determinants of perceived service quality and its relationship with satisfaction. Journal of services marketing 14(3): 217-231.

Liao, N.N.H. and Wu, T.C. (2009) The pivotal role of trust in customer loyalty: Empirical research on the system integration market in Taiwan. The Business Review 12(2): 277-282.

Lindblom-Ylänne, S., Trigwell, K., Nevgi, A. and Ashwin, P. (2006) How approaches to teaching are affected by discipline and teaching context. Studies in Higher Education 31: 285-298.

Lynch, K. (2015) Control by numbers: New managerialism and ranking in higher education. Critical Studies in Education 56(2): 190-207.

Mael, F. and Ashforth, B.E. (1992) Alumni and their alma mater: A partial test of the reformulated model of organizational identification. Journal of Organizational Behaviour 13(2): 103-123.

Malhotra, N.K. and Birks, D.F. (2007) Marketing research: An applied approach. Pearson Education.

Malik, S.A., Mushtaq, A., Jaswal, L.H. and Malik, S.A. (2015) Survey on marketing tactics used to build private school image and increase parents' loyalty. International Journal of Management in Education 9(2): 180-199.

Marzo, M., Pedraja, M., and Rivera, P. (2007) The customer concept in university services: A classification. International Review on Public and Non Profit Marketing 4(1/2): 65-80.

Mazzarol, T. and Soutar, G.N. (2002) Push-pull' factors influencing international student destination choice. International Journal of Educational Management 16(2): 82-90.

Melewar, T.C. and Akel, S. (2005) The role of corporate identity in the higher education sector: A case study. Corporate Communications: An International Journal 10(1): 41-57.

Mihanović, Z., Batinić, A.B. and Pavičić, J. (2016) The link between students' satisfaction with faculty, overall students' satisfaction with student life and student performances. Review of Innovation and Competitiveness: A Journal of Economic and Social Research 2(1): 37-60.

Morgan, R.M., and Hunt, S.D. (1994) The commitment-trust theory of relationship marketing. Journal of Marketing 58(3): 20-38.

Mourad, M., Meshreki, H. and Sarofim, S. (2019) Brand equity in higher education: comparative analysis. Studies in Higher Education 1-23.

Nam, J., Ekinci, Y. and Whyatt, G. (2011) Brand equity, brand loyalty and consumer satisfaction. Annals of Tourism Research 38(3): 1009-1030.

Ndirangu, M. and Udoto, M.O. (2011) Quality of learning facilities and learning environment: Challenges for teaching and learning in Kenya's public universities. Quality Assurance in Education 19(3): 208-223.

Neumann, R. (2001) Disciplinary differences and university teaching. Studies in Higher Education 26(2): 135-146.

Neumann, R., Parry, S. and Becher, T. (2002) Teaching and learning in their disciplinary context: A conceptual analysis. Studies in Higher Education 27(4): 405-417.

$\mathrm{Ng}$, I. and Forbes, J. (2009) Education as service: The understanding of university experience through the service logic. Journal of Marketing for Higher Education 19(1): 38-64.

Nguyen, N. and LeBlanc, G. (2001) Image and reputation of higher education institutions in students' retention decisions. International Journal of Educational Management 15(6): 303-311.

Nunnally, J.C. and Bernstein, I.H. (1994) Psychometric Theory. New York: McGraw-Hill.

Oliver, R.L. (1999) Whence consumer loyalty?. Journal of Marketing 63(4): 33-44.

Opoku, R.A., Hultman, M. and Saheli-Sangari, E. (2008) Positioning in market space: The evaluation of Swedish universities' online brand personalities. Journal of Marketing for Higher Education 18(1): 124-144.

Palmer, A., Koenig-Lewis, N. and Asaad, Y. (2016) Brand identification in higher education: A conditional process analysis. Journal of Business Research 69(8): 3033-3040.

Peng, P.J. and Samah, A.J.A. (2006) Measuring Students' Satisfaction for Quality Education in a e-learning university. Unitar E-Journal 2(1): 11-21.

Pinar, M., Trapp, P., Girard, T. and Boyt, T. (2011) Utilizing Brand Ecosystem for Branding and Building Brand Equity in Higher Education. International Journal of Educational Management 25(7): 724-739. 
Pinar, M., Trapp, P., Girard, T. and Boyt, T. (2014) University brand equity: an empirical investigation of its dimensions. International Journal of Educational Management 28(6): 616-634.

Price, I.F., Matzdorf, F., Smith, L. and Agahi, H. (2003) The impact of facilities on student choice of university. Facilities 21(10): 212-222.

Quelch JA. and Laidler-Kylander N. (2006) The New Global Brands: Managing Non-Government Organizations in the 21st Century. Ohio: Thomson, South-Western.

Rauschnabel, P.A., Krey, N., Babin, B.J. and Ivens, B.S. (2016) Brand management in higher education: The University Brand Personality Scale. Journal of Business Research 69(8): 3077-3086.

Rindfleish, J.M. (2003) Segment profiling: Reducing risk in higher education management. Journal of Higher Education Policy and Management 25(2): 147-159.

Rolfe, H. (2003) University strategy in an age of uncertainty: The effect of higher education funding on old and new universities. Higher Education Quarterly 57(1): 24-47.

Safon, V. (2009) Measuring the reputation of top US business schools: a MIMIC modelling approach. Corporate Reputation Review 12(3): 204-228.

Sander, P., Stevenson, K., King, M. and Coates, D. (2000) University students' expectations of teaching. Studies in Higher education 25(3): 309-323.

Schiffman, L.G. and Kanuk, L.L. (2007) Consumer Behaviour. Upper Saddle River, NJ: Pearson Prentice Hall.

Sevier, R.A. (2001) Brand as relevance. The Journal of Marketing for Higher Education 10(3): 77-96.

Stephenson, A.L. and Yerger, D.B. (2014) Does brand identification transform alumni into university advocates?. International Review on Public and Nonprofit Marketing 11(3): 243-262.

Sung, M. and Yang, S.U. (2009) Student-university relationships and reputation: A study of the links between key factors fostering students' supportive behavioural intentions towards their university. Journal of Higher Education 57(6): 787-811.

Swarat, S., Oliver, P.H., Tran, L., Childers, J.G., Tiwari, B. and Babcock, J.L. (2017) How disciplinary differences shape student learning outcome assessment: a case study. AERA Open 3(1): 1-12.

Temple, P. (2006) Branding higher education: illusion or reality?. Perspectives: Policy and Practice in Higher Education 10(1): 15-19.

Thomas, E.H. and Galambos, N. (2004) What satisfies students? Mining student-opinion data with regression and decision tree analysis. Research in Higher Education 45(3): 251-269.

Umbach, P.D. and Porter, R. (2002) How do academic departments impact student satisfaction?. Understanding the contextual effects of departments. Research in Higher Education 43(4): 209-234.

Valette-Florence, R. and De Barnier, V. (2013) Towards a micro conception of brand personality: An application for print media brands in a French context. Journal of Business Research 66(7): 897-903.

Van Vught, F. (2008) Mission diversity and reputation in higher education. Higher Education Policy 21(2): 151174.

Wæraas, A. and Solbakk, M.N. (2008) Defining the essence of a university: Lessons from higher education branding. Higher education 57(4): 449-462.

Watkins, B.A. and Gonzenbach, W.J. (2013) Assessing university brand personality through logos: An analysis of the use of academics and athletics in university branding. Journal of Marketing for Higher Education 23(1): 15-33.

Wilkins, S. and Huisman, J. (2011) Student recruitment at international branch campuses: Can they compete in the global market?. Journal of Studies in International Education 15(3): 299-316.

Yavas, U. and Shemwell, D.J. (1996) Graphical representation of university image: a correspondence analysis. Journal of Marketing for Higher Education 7(2): 75-84.

Yu, Q., Asaad, Y., Yen, D.A. and Gupta, S. (2018) IMO and internal branding outcomes: an employee perspective in UK HE. Studies in Higher Education 43(1): 37-56.

Zeithaml, V.A. (1988) Consumer perceptions of price quality and value: A means end model and synthesis of evidence. Journal of Marketing 55(7): 2-22.

Zeithaml, V.A., Berry, L.L. and Parasuraman, A. (1996) The behavioural consequences of service quality. Journal of Marketing 60(2): 31-46. 
Appendix

\begin{tabular}{|c|c|c|}
\hline CONSTRUCT & ITEMS & \multirow{14}{*}{ Cronin and Taylor (1992) } \\
\hline \multirow{13}{*}{$\begin{array}{l}\text { TEACHING } \\
\text { STAFF }\end{array}$} & SQProf1. Qualification of teaching staff & \\
\hline & SQProf2. Currency of teaching staff training & \\
\hline & SQProf3. Ability to use information technology to support student learning & \\
\hline & SQProf4. Individual attention to students & \\
\hline & SQProf5. Ability to understand the needs of the students & \\
\hline & SQProf6. Ability to solve students' problems & \\
\hline & SQProf7. Ability to deliver the unit programme & \\
\hline & SQProf8. Quality of the learning materials & \\
\hline & SQProf9. Delivers scheduled classes on time & \\
\hline & SQProf10. Time it takes to return exams and coursework & \\
\hline & SQProf11. Predisposition to offer help to students & \\
\hline & SQProf12. Adequate assessment and grading methods & \\
\hline & SQProf13. Fluid communication with students & \\
\hline \multirow{11}{*}{ LOYALTY } & Loyal1. If I was faced with the same choice again, I'd still choose UCLM & \multirow{11}{*}{$\begin{array}{l}\text { Fornell (1992); Selnes } \\
\text { (1993); Nguyen and } \\
\text { LeBlanc (2001); Arnett, } \\
\text { German and Hunt (2003); } \\
\text { Ahearne, Bhattacharya and } \\
\text { Gruen (2005); Alves (2011); } \\
\text { Grace, Weaven, Bodey, } \\
\text { Ross and Weaven (2012) }\end{array}$} \\
\hline & Loyal2. If I had to do another course l'd consider UCLM as the first option & \\
\hline & Loyal3. If anyone asks me for advice about universities l'd recommend UCLM & \\
\hline & Loyal4. Occasionally I say positive things about UCLM to my friends and family (Removed) & \\
\hline & Sat1. I am satisfied with UCLM compared with my ideal choice & \\
\hline & Sat2. I am satisfied with UCLM in terms of my expectations & \\
\hline & Sat3. Overall, I am satisfied with my decision to study at UCLM & \\
\hline & $\begin{array}{l}\text { PValue1. Considering the time, effort and money invested I consider adequate the value } \\
\text { received (Removed) }\end{array}$ & \\
\hline & PValue2. I consider studying at UCLM a good decision & \\
\hline & $\begin{array}{l}\text { PValue3. When comparing the results with the sacrifices made, my evaluation of studying at } \\
\text { UCLM is positive }\end{array}$ & \\
\hline & $\begin{array}{l}\text { PValue4. The experience l'm gaining in this course will be valuable for my professional } \\
\text { career }\end{array}$ & \\
\hline \multirow{9}{*}{ COMMUNITY } & Community1. When someone criticizes UCLM, it feels like a personal criticism & \multirow{9}{*}{$\begin{array}{c}\text { Mael and Ashforth (1992); } \\
\text { Bergkvist and BechLarsen } \\
\text { (2010); Nam, Ekinci and } \\
\text { Whyatt (2011) }\end{array}$} \\
\hline & Community2. You are very interested in what others think about UCLM & \\
\hline & Community3. When you talk about UCLM, you usually say 'we' rather than 'they' & \\
\hline & Community4. UCLM successes are my own successes & \\
\hline & Community5. When someone compliments UCLM it feels like a personal compliment & \\
\hline & Community6. It bothers me If I see a story in the media criticising UCLM & \\
\hline & BLove1. Comparing with other universities, UCLM is my favourite (Removed) & \\
\hline & BLove2. I have positive feelings towards UCLM that I don't have towards others (Removed) & \\
\hline & BLove3. I feel a personal connection with UCLM & \\
\hline \multirow{6}{*}{$\begin{array}{l}\text { ADMINISTRATIV } \\
\text { E STAFF }\end{array}$} & SQAdm1. Ability of admin staff to fulfil their duties & \multirow{6}{*}{ Cronin and Taylor (1992) } \\
\hline & SQAdm2. Ability of admin staff to understand the student needs & \\
\hline & SQAdm3. Individual attention when interacting with students & \\
\hline & SQAdm4. Time it takes to complete a task & \\
\hline & SQAdm5. Enrolment and transcript service & \\
\hline & SQAdm6. Predisposition to provide support & \\
\hline \multirow{10}{*}{$\begin{array}{l}\text { STUDY } \\
\text { PROGRAMME }\end{array}$} & SQStudy1. Study programme appropriate to the needs of the students (Removed) & \multirow{10}{*}{ Cronin and Taylor (1992) } \\
\hline & SQStudy2. Complementary training (seminars, specialization courses...) & \\
\hline & SQStudy3. Training opportunities in companies/organizations & \\
\hline & SQStudy4. Postgraduate programs appropriate to student needs & \\
\hline & SQStudy5. International mobility & \\
\hline & SQStudy6. Employability services & \\
\hline & SQStudy7. Availability of complementary services (sports, culture, library) & \\
\hline & Focus1. Close to students (Removed) & \\
\hline & Focus2. Close to society (Removed) & \\
\hline & Focus3. Close to companies & \\
\hline \multirow{6}{*}{$\begin{array}{c}\text { FACILITIES AND } \\
\text { EQUIPMENT }\end{array}$} & SQFac1. Teaching equipment on campus & \multirow{6}{*}{ Cronin and Taylor (1992) } \\
\hline & SQFac2. Campus Virtual (intranet) & \\
\hline & SQFac3. Campus buildings and facilities & \\
\hline & SQFac4. Location of the campus buildings & \\
\hline & SQFac5. Ease of access to buildings & \\
\hline & SQFac6. Library resources & \\
\hline & Pers1. Prestigious (Removed) & \\
\hline & Pers2. Good reputation (Removed) & \\
\hline & Pers3. Modern/Innovative (Removed) & \\
\hline BRAND & Pers4. Young & Beerli, Díaz and Pérez \\
\hline PERSONALITY & Pers5. Pleasant & (2002) \\
\hline & Pers6. Stimulating & \\
\hline & Pers7. Dynamic & \\
\hline & Pers8. Happy & \\
\hline & SHValues1. The values of UCLM are consistent with your own personal values & \\
\hline SHARED & SHValues2. UCLM values reflect the type of person you are & \\
\hline VALUES & SHValues3. UCLM values are compatible with the things you think & Morgan and Hunt (1994) \\
\hline & SHValues4. UCLM values are similar to your values & \\
\hline & Trust1. For me, UCLM is a sincere and honourable institution & \\
\hline & Trust2. UCLM has a high level of integrity & \\
\hline BRAND TRUST & Trust3. I can totally trust in UCLM & Morgan and Hunt (1994) \\
\hline & Trust4. UCLM acts in an appropriate way in all situations & \\
\hline
\end{tabular}


